\title{
Proficiency testing in immunohaematology in Ontario, Canada, and in the United Kingdom: a comparative study
}

\author{
PH PINKERTON, ${ }^{*}$ ED ZUBER, ${ }^{*}$ DE WOOD, ${ }^{*}$ AM HOLBURN, $†$ D PRIOR $\dagger$ \\ From the *Laboratory Proficiency Testing Program, Ontario Medical Association, Toronto, Ontario, \\ Canada, and the †United Kingdom National External Quality Assessment Scheme, Blood Group Reference \\ Laboratory, Oxford, United Kingdom
}

SUMMARY A comparative study of proficiency testing models in immunohaematology has been carried out between the United Kingdom National External Quality Assessment Scheme and the Laboratory Proficiency Testing Program of the Ontario Medical Association, using material supplied by both programmes to laboratories in the United Kingdom and Ontario. The results suggest that the general standard of performance in immunohaematology practice is similar in the two jurisdictions and that, where clear differences are seen, these reflect differences in technique or in educational emphasis.

Proficiency testing programmes in immunohaematology have been developed in several jurisdictions including Australia, Ontario, the United Kingdom, and the United States. In each jurisdiction the testing model and mode of presentation of results differ and it is difficult to estimate comparative standards of performance. In an attempt to obtain such an estimate, proficiency testing material has been exchanged between the Laboratory Proficiency Testing Program (LPTP) of the Ontario Medical Association ${ }^{12}$ and the United Kingdom National External Quality Assessment Scheme (UK NEQAS). ${ }^{34}$ We report here the results of this comparative study.

\section{Material and methods}

In the first part of the study 68 volunteer laboratories in the United Kingdom and 53 volunteer laboratories in Ontario received survey material supplied by the UK NEQAS. The 68 UK laboratories comprised the majority of hospitals in two metropolitan regions but were otherwise unselected. The 53 volunteer laboratories in Ontario included those of Canadian Red Cross Blood Transfusion Services and laboratories in hospitals with 250 beds or more, these being chosen to be as similar as possible to the laboratories in the

Accepted for publication 25 January 1985
UK with which they were to be compared. Details of the material used are given in Table 1. Laboratories were instructed to crossmatch each of five serum samples with each of three cells using their usual techniques and to record the reaction strength according to the prescribed code on report forms supplied by UK NEQAS. ${ }^{4}$ Results were analysed, tabulated, and communicated to participating laboratories.

In the second part of the study 49 laboratories in the United Kingdom and 52 in Ontario participated using survey material from LPTP, supplied by Gamma Biologicals (Houston, Texas) and using LPTP's reporting format. ' Details of the material used are given in Table 2. All participants were asked to perform $\mathrm{ABO}$ and $\mathrm{Rh}(\mathrm{D})$ grouping and antibody screening procedures using their usual techniques and to record the reaction strengths according to the prescribed code on report forms supplied by LPTP.' Results were analysed, tabulated, and communicated to participating laboratories.

\section{Results}

UK NEQAS DESIGNED SURVEY

The study using UK NEQAS material only required crossmatching of five serum samples to three cells. The number of laboratories failing to detect antibodies in the test samples by any method used (mis- 
Table 1 Material supplied by United Kingdom National External Quality Assessment Scheme for testing of United Kingdom and Ontario laboratories

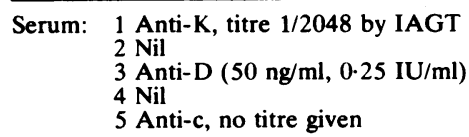

Cells: $\quad \mathbf{W} 0 ; \mathbf{R}_{1} \mathbf{R}_{1} ; \mathrm{K}-$

$\mathrm{Y} 0 ; \mathbf{r r} ; K^{1}-$

$\mathrm{Z} 0 ; \mathbf{R}, \mathbf{r} ; \mathrm{K}+$

There were five incompatibilities: Serum 1 with cell $Z$

Serum 3 with cells $W$ and $Z$ Serum 5 with cells $Y$ and $Z$

Table 2 Material supplied by Laboratory Proficiency Testing Program in Ontario for testing of United Kingdom and Ontario laboratories

\begin{tabular}{|c|c|}
\hline $\begin{array}{l}\text { I-8310-1 } \\
\text { I-8310-2 } \\
\text { I-8310-3 } \\
\text { I-8310-4 } \\
\text { I-8310-5 }\end{array}$ & $\begin{array}{l}\text { B } R h(D) \text { Positive } \\
0 \mathrm{Rh}(\mathrm{D}) \text { Positive, anti-K present in serum } \\
\mathrm{A}_{2} \mathrm{Rh}(\mathrm{D}) \text { Negative, positive direct } \\
\text { antiglobulin test } \\
0 \mathrm{Rh}(\mathrm{D}) \text { Negative, anti-D present in serum } \\
(124 \mathrm{ng} / \mathrm{ml}, 0.62 \mathrm{IU} / \mathrm{ml}) \\
\mathrm{A}_{2} \mathrm{~B} \mathrm{Rh}(\mathrm{D}) \text { Positive, anti- } \mathrm{A}_{1} \text { present in serum }\end{array}$ \\
\hline
\end{tabular}

Table 3 Missed incompatibilities (false negative reports)

\begin{tabular}{|c|c|c|c|c|}
\hline \multirow[t]{2}{*}{ Serum } & \multirow[t]{2}{*}{ Antibody } & \multirow[t]{2}{*}{ Cell } & \multicolumn{2}{|c|}{$\begin{array}{l}\text { Proportion of laboratories } \\
\text { missing incompatibility (\%) }\end{array}$} \\
\hline & & & $\begin{array}{l}\text { Ontario } \\
(n=53)\end{array}$ & $\begin{array}{l}U K \\
(n=68)\end{array}$ \\
\hline $\begin{array}{l}\text { Serum 1 } \\
\text { Serum } 3 \\
\text { Serum } 3 \\
\text { Serum } 5 \\
\text { Serum } 5\end{array}$ & $\begin{array}{l}\text { (anti-K) } \\
\text { (anti-D) } \\
\text { (anti-D) } \\
\text { (anti-c) } \\
\text { (anti-c) }\end{array}$ & $\begin{array}{l}Z(K+) \\
W\left(R_{1} R_{1}\right) \\
Z\left(R_{1}\right) \\
Y(r r) \\
Z\left(R_{1} r\right)\end{array}$ & $\begin{array}{l}0 \\
0 \\
0 \\
1 \cdot 9 \\
47 \cdot 2\end{array}$ & $\begin{array}{r}1 \cdot 5 \\
2.9 \\
2 \cdot 9 \\
8 \cdot 8 \\
35 \cdot 3\end{array}$ \\
\hline
\end{tabular}

sed incompatibilities) is shown in Table 3 . In the detection of strong irregular antibodies, Ontario laboratories fared somewhat better than UK laboratories, but they had more difficulty than UK laboratories with the reaction between the weak anti-c (serum 5) with the heterozygous c cell (cell $Z$ ). The anti-c in serum 5 was better detected when albumin displacement or enzyme methods were used. A surprisingly large number of Ontario laboratories obtained false positive reactions, mainly weak or very weak, in the antiglobulin phase only (Table 4).

\section{LPTP DESIGNED SURVEY}

Results of the study using the Ontario LPTP material are given in Tables 5 and 6 . There was no obvious difference in performance in cell typing except when rhesus typing was complicated by the presence of a positive direct antiglobulin test. This was seen both in $R h(D)$ typing and in rhesus phenotyping (which was not a required part of this survey), where UK laboratories had much more difficulty in reaching the correct interpretation than Ontario laboratories. There was no significant difference in the quality of antibody detection. Table 7 gives the number of laboratories reporting identification of antibodies detected. All laboratories which reported identification of the antibodies supplied did so correctly. Strengths of reaction reported by UK and Ontario laboratories for detection of anti- $K$ and anti- $\mathrm{D}$, using albumin enhanced direct agglutination methods at $37^{\circ} \mathrm{C}$ and antiglobulin methods, are shown in the Figure. In the hands of UK laboratories the direct agglutination methods were more sensitive, but little difference was seen in sensitivity of indirect antiglobulin testing in this part of the study.

Table 4 Apparent false positive reactions (antiglobulin test only)

\begin{tabular}{|c|c|c|c|c|c|c|c|c|c|}
\hline \multirow[t]{2}{*}{ Serum } & \multirow[t]{2}{*}{ Cell } & \multirow{2}{*}{$\begin{array}{l}\text { Ontario } \\
\text { reference } \\
\text { laboratory }\end{array}$} & \multicolumn{5}{|c|}{ Number of Ontario results } & \multicolumn{2}{|c|}{ Percent "positive" } \\
\hline & & & 0 & \pm & + & ++ & ++ & $\begin{array}{l}\text { Ontario } \\
(n=53)\end{array}$ & $\begin{array}{l}U K \\
(n=68)\end{array}$ \\
\hline $\begin{array}{l}1 \\
1 \\
2 \\
2 \\
2 \\
3 \\
4 \\
4 \\
4 \\
5\end{array}$ & $\begin{array}{l}\mathbf{W} \\
\mathbf{Y} \\
\mathbf{W} \\
\mathbf{Y} \\
\mathbf{Z} \\
\mathbf{Y} \\
\mathbf{W} \\
\mathbf{Y} \\
\mathbf{Z} \\
\mathbf{W}\end{array}$ & $\begin{array}{l} \pm \\
\pm^{*} \\
0 \\
0 \\
0 \\
\pm^{*} \\
\pm \\
\pm^{*} \\
0 \\
\pm\end{array}$ & $\begin{array}{l}40 \\
47 \\
42 \\
47 \\
49 \\
45 \\
41 \\
41 \\
51 \\
40\end{array}$ & $\begin{array}{r}9 \\
4 \\
8 \\
2 \\
0 \\
3 \\
6 \\
5 \\
1 \\
11\end{array}$ & $\begin{array}{l}4 \\
2 \\
3 \\
3 \\
4 \\
5 \\
4 \\
6 \\
1 \\
2\end{array}$ & $\begin{array}{l}0 \\
0 \\
0 \\
1 \\
0 \\
0 \\
2 \\
1 \\
0 \\
0\end{array}$ & $\begin{array}{l}0 \\
0 \\
0 \\
0 \\
0 \\
0 \\
0 \\
0 \\
0 \\
0\end{array}$ & $\begin{array}{r}24.5 \\
11.3 \\
20.7 \\
11.3 \\
7.5 \\
15.1 \\
22.6 \\
22.6 \\
3.8 \\
24.5\end{array}$ & $\begin{array}{c}2.9 \\
1.5 \\
1.5 \\
1 \cdot 5 \\
25 \cdot 0 \\
2.9 \\
0 \\
1 \cdot 5 \\
0 \\
2.9\end{array}$ \\
\hline Total & & & 443 & 49 & 34 & 4 & 0 & & \\
\hline
\end{tabular}

*Negative on repeat testing. Other reference laboratory results remained unchanged on repeat testing. 
Table 5 Comparative results in $49 \mathrm{UK}$ and 53 Ontario laboratories using the Ontario material: cell typing and direct antiglobulin test (DAGT)

\begin{tabular}{|c|c|c|c|c|}
\hline \multirow[t]{2}{*}{ Test } & \multicolumn{2}{|c|}{ Number of opportunities for error } & \multicolumn{2}{|c|}{ Percent error } \\
\hline & $U K$ & Ontario & $U K$ & Ontario \\
\hline $\begin{array}{l}\text { Uncomplicated } A B O \text { grouping } \\
\text { ABO interpretation } A_{2} B \text { with anti- } A_{1} \\
\text { Uncomplicated } R h(D) \text { grouping } \\
\text { Rh(D) interpretation } R h(D) \text { negative }\end{array}$ & $\begin{array}{r}196 \\
49 \\
196\end{array}$ & $\begin{array}{r}208 \\
52 \\
208\end{array}$ & $\begin{array}{l}0 \\
2 \\
1\end{array}$ & $\begin{array}{l}0 \\
1 \cdot 9 \\
0\end{array}$ \\
\hline $\begin{array}{l}\text { with positive DAGT } \\
\text { Uncomplicated Rh phenotyping (not }\end{array}$ & 49 & 52 & $42 \cdot 9$ & $1 \cdot 9$ \\
\hline $\begin{array}{l}\text { required by testing model) } \\
\text { Rh phenotyping with positive DAGT }\end{array}$ & 190 & 93 & $4 \cdot 2$ & $2 \cdot 1$ \\
\hline $\begin{array}{l}\text { (not required by testing model) } \\
\text { False positive and false negative DAGT }\end{array}$ & $\begin{array}{r}49 \\
235\end{array}$ & $\begin{array}{r}42 \\
245\end{array}$ & $\begin{array}{c}16 \cdot 3 \\
0\end{array}$ & $\begin{array}{l}0 \\
0\end{array}$ \\
\hline
\end{tabular}

Table 6 Comparative results in antibody detection using the Ontario material

\begin{tabular}{|c|c|c|c|c|}
\hline \multirow[t]{2}{*}{ Antibody } & \multicolumn{2}{|c|}{ Number of laboratories testing material } & \multicolumn{2}{|c|}{ Proportion of laboratories failing to detect antibody } \\
\hline & $U K$ & Ontario & $U K$ & Ontario \\
\hline $\begin{array}{l}\text { Anti-K } \\
\text { Anti-D (124 ng/ml) } \\
\text { Anti-A }_{1}\end{array}$ & $\begin{array}{l}49 \\
49 \\
49\end{array}$ & $\begin{array}{l}52 \\
52 \\
52\end{array}$ & $\begin{array}{l}2 \% \\
0 \\
6 \cdot 1 \%\end{array}$ & $\begin{array}{l}0 \\
0 \\
1.9 \%\end{array}$ \\
\hline
\end{tabular}

Table 7 Laboratories reporting identification of antibodies detected using the Ontario material

\begin{tabular}{|c|c|c|c|c|c|c|}
\hline \multirow[t]{3}{*}{ Antibody } & \multicolumn{3}{|l|}{ UK participants } & \multicolumn{3}{|l|}{ Ontario participants } \\
\hline & \multirow{2}{*}{$\frac{\text { Detected antibody }}{\text { Number }}$} & \multicolumn{2}{|c|}{ Identified antibody } & \multirow{2}{*}{$\frac{\text { Detected antibody }}{\text { Number }}$} & \multicolumn{2}{|c|}{ Identified antibody } \\
\hline & & Number & (\%) & & Number & $(\%)$ \\
\hline $\begin{array}{l}\text { Anti-K } \\
\text { Anti-D } \\
\text { Anti- } A_{1}\end{array}$ & $\begin{array}{l}48 \\
49 \\
46\end{array}$ & $\begin{array}{l}40 \\
41 \\
31\end{array}$ & $\begin{array}{l}(83 \cdot 3) \\
(83 \cdot 7) \\
(67 \cdot 4)\end{array}$ & $\begin{array}{l}52 \\
52 \\
51\end{array}$ & $\begin{array}{l}51 \\
51 \\
47\end{array}$ & $\begin{array}{l}(98 \cdot 1) \\
(98 \cdot 1) \\
(92 \cdot 2)\end{array}$ \\
\hline
\end{tabular}

\section{Discussion}

No difference in performance was found between the Ontario and UK laboratories tested in respect of uncomplicated $\mathrm{ABO}$ and $\mathrm{Rh}(\mathrm{D})$ typing and direct antiglobulin testing. In the detection of strong irregular antibodies Ontario laboratories performed slightly better. Detection of a weak anti-c gave laboratories in both jurisdictions difficulty. The fact that this antibody was better detected with enzyme and albumin displacement methods may account for the higher rate of positive reactions between this anti-c and heterozygous $\left(R_{1} r\right)$ cells seen in $U K$ laboratories since these methods have much wider use in the UK than in Ontario. In routine daily practice, however, it is unlikely that many Ontario laboratories would have missed this antibody since it reacted well in the antiglobulin phase with homozygous c cells-that is, cell $\mathrm{Y}, \mathrm{rr}$ - which are usually included as screening cells in crossmatching procedures. Laboratories in the UK had difficulty in $\mathrm{Rh}(\mathrm{D})$ typing in the presence of a strongly positive antiglobulin test. Similar difficulties were experi- enced by Ontario laboratories in early surveys - for example, $30.6 \%$ error rate in $1977 .{ }^{2}$ Since then LPTP has used educational measures to promote the use of adequate controls in rhesus testing and has reinforced recognition of this problem by sending $\mathrm{Rh}(\mathrm{D})$ negative cells with a positive direct antiglobulin test to participants from time to time. The recent introduction of chemically modified anti-D may also have contributed to a reduction in errors of $\mathrm{Rh}(\mathrm{D})$ interpretation in this situation. This problem in proficiency testing has received particular attention in Ontario because it is believed to provide an indication of understanding of fundamental principles of blood group antigen detection and identification.

The reasons for the high incidence of apparent false positive reactions with the UK testing material in Ontario compared with UK are not clear. LPTP data for 1983 surveys show a false positive rate of $0.3 \%$ with LPTP's usual survey material (Zuber ED, unpublished observations). Possible factors include over-reading, unfamiliarity with the UK testing model in Ontario, differences in sensitivity of 


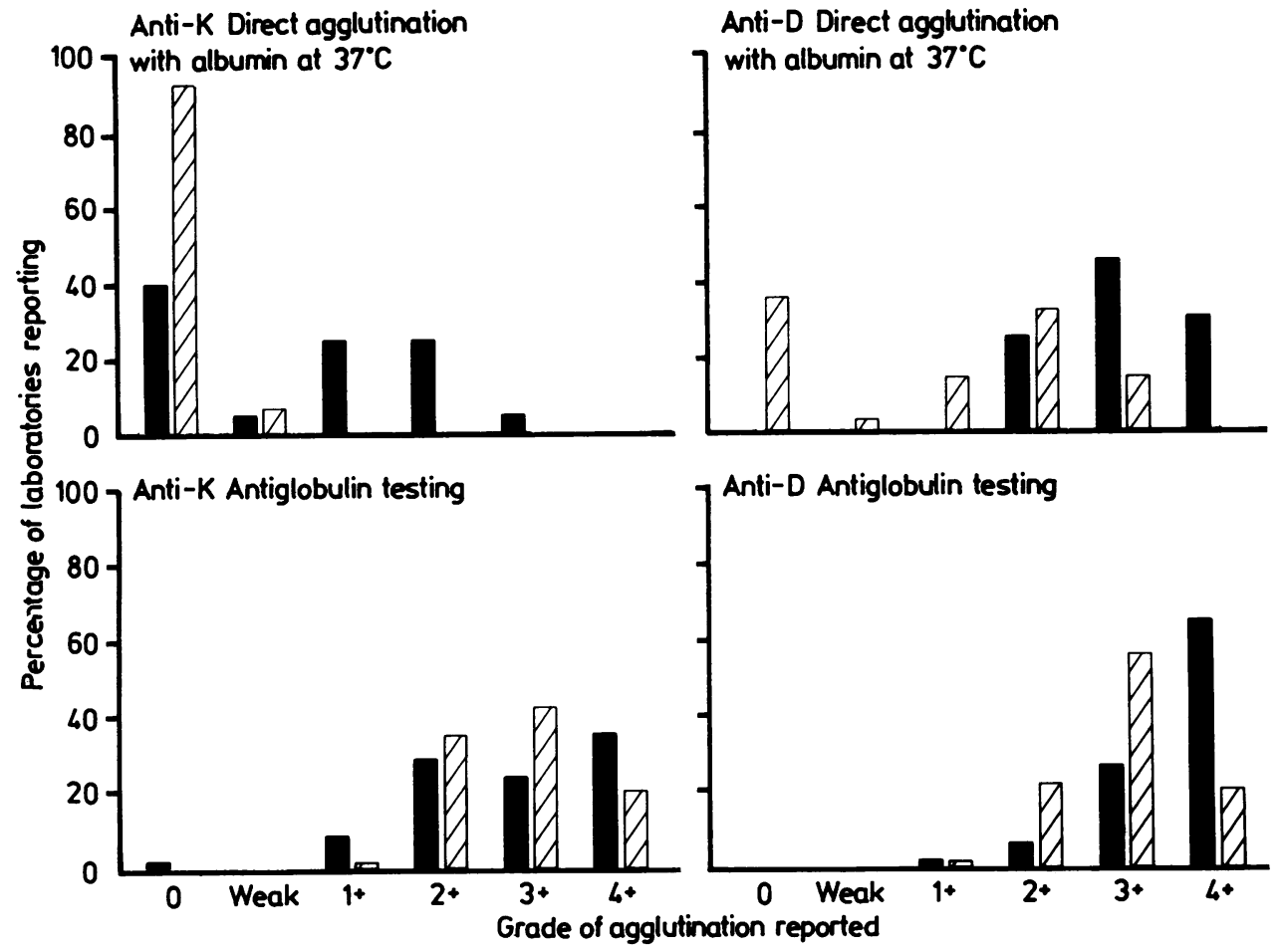

Comparison of strengths of reaction reported by $U K$ and Ontario participants using various techniques with the anti- $D$ and anti-K supplied by the Ontario Laboratory Proficiency Testing Program. The solid bars represent $U K$ laboratories and the cross hatched bars represent Ontario laboratories.

antiglobulin reagents, constraints of the testing model in preventing further investigation of such problems, and damage to test material in transit. It is not possible to assess the role of each or any of these factors in producing the high frequency of apparent false positive reactions. The weak false positive reactions were seen only in the antiglobulin phase of testing. The high incidence of false positive results with cell $\mathrm{Z}$ and serum 2 in the UK laboratories may represent carry over of anti-Kell from serum 1, a phenomenon observed previously with potent antibodies in UK NEQAS testing (Holburn AM, unpublished observations).

The anti- $K$ and anti- $D$ in the LPTP designed survey were not readily detectable by saline techniques at $37^{\circ} \mathrm{C}$ but were detectable by albumin, enzyme, and indirect antiglobulin techniques. A comparison of the strength of reactivity reported by UK and LPTP participants for albumin and indirect antiglobulin techniques for these two antibodies shows better detection by UK participants with direct albumin agglutination methods. This is presumably explained by the fact that UK participants often use an albumin displacement (layering) technique while LPTP participants often use a technique in which cells are mixed and incubated with both serum and albumin. The former method is believed to be more sensitive. ${ }^{5}$ The strengths of reactivity reported for the indirect antiglobulin test show little difference.

This comparative study of the UK NEQAS and the Ontario LPTP testing models has shown few differences in quality of performance of basic techniques in the two jurisdictions. Where major differences in performance were found they were readily explained by local differences in technique or educational emphasis. Further development of comparative studies of this nature should permit clearer definition of reasonable expectations of laboratories participating in proficiency testing or external quality assessment and so allow politically acceptable and technically achievable objectives to be set.

This study was supported in part by a grant from the Physicians' Services Incorporated Foundation, Ontario, Canada. The UK NEQAS is supported by the Department of Health and Social Services. 


\section{References}

' Ezer SC, Burnie KL, Carstairs KC, et al. A system for proficiency testing in immunohaematology. Clin Lab Haematol 1981;3:143-53.

2 Pinkerton PH, Wood DE, Burnie KL, et al. Proficiency testing in immunohaematology in Ontario, Canada, 1977-79. Clin Lab Haematol 1981;3:155-64.

${ }^{3}$ Holburn AM. Quality assurance and standardization in blood group serology. In: Cavill I, ed. Methods in hematology, 4, Quality Control. New York: Churchill Livingstone 1982:34 50 .
${ }^{4}$ Holburn AM, England JM. The UK National External Quality Assessment Scheme in Blood Group Serology. Compatibility testing 1979-1980. Clin Lab Haematol 1982;4:3-12.

5 Widmann FK, ed. Technical manual of the American Association of Blood Banks, 8th ed. Philadelphia: JB Lippincott, 1981:180.

Requests for reprints to: Dr DE Wood, Laboratory Proficiency Testing Program, Ontario Medical Association, 250 Bloor Street East, Suite 1501, Toronto, Ontario M4W 1E6, Canada. 